\title{
Sorbents Used for Biogas Desulfurization in the Adsorption Process
}

\author{
Justyna Kwaśny*, Wojciech Balcerzak \\ Institute of Water Supply and Environmental Protection, Faculty of Environmental Engineering, \\ Cracow University of Technology \\ Warszawska 24, 31-155 Cracow, Poland
}

Received: 8 July 2015

Accepted: 16 October 2015

\begin{abstract}
Our paper discusses the issue of biogas desulfurization with adsorbents. The authors investigated biogas in terms of the relationship between anaerobic digestion substrates and a chemical composition of the product. Based on the literature review, each group of adsorbents and their representatives was examined, with special attention paid to carbon and mineral adsorbents. The authors analyzed the desulfurization process using in particular activated carbon, oxide adsorbents, and zeolites.
\end{abstract}

Keywords: biogas, desulfurization, activated carbon, zeolites, oxide adsorbents

\section{Introduction}

A gas mixture produced during anaerobic digestion has considerable potential as an alternative energy source. Unfortunately, currently it can be used only on site due to its contamination by gaseous pollutants such as $\mathrm{CO}_{2}, \mathrm{H}_{2} \mathrm{~S}$, water vapor, etc., whose presence prevents transferring and transporting this renewable fuel. On the other hand, biogas purified and enriched with methane can be used as a fuel for domestic uses, automobiles, and for electricity generation [1]. Hence, there is a need and necessity for biogas desulfurization and purification in order to increase its possible applications.

Removal of $\mathrm{H}_{2} \mathrm{~S}$ from biogas is critical to successful applications of gasification techniques, mainly due to possible future operation problems such as corrosion of pipes, turbines, or other transmission units.

*e-mail: kwasny.justyna@gmail.com
Desulfurization of biogas is also an important issue in solving environmental problems like global warming and acid rain [2].

This paper presents characteristics of biogas in terms of its chemical composition and discusses the process of its desulfurization using adsorption methods.

\section{Biogas and its Characteristics}

Biogas is a product of anaerobic digestion of organic matter of various origin. It is used as a renewable energy source and also a renewable fuel that can be used in fuel cells [3]. Chemically, biogas is a mixture of gases such as methane, $\mathrm{CO}_{2}, \mathrm{H}_{2} \mathrm{~S}$, water vapor, and others [4-6]. A biogas composition varies depending on the origin of the raw materials [7], as shown in Table 1 [8].

Bocci et al. [5] determined a general chemical biogas composition regardless of origin. The contents of methane, carbon dioxide, water vapor, halogenated hydrocarbons, and nitrogen relative to oxygen is, respectively, 
Table 1. Biogas composition for different substrates of anaerobic digestion [8].

\begin{tabular}{|c|c|c|c|c|c|}
\hline Component & Unit & $\begin{array}{l}\text { Domestic } \\
\text { waste }\end{array}$ & $\begin{array}{l}\text { Sludge from wastewa- } \\
\text { ter treatment plants }\end{array}$ & Agricultural waste & $\begin{array}{l}\text { Waste from the } \\
\text { agro-food industry }\end{array}$ \\
\hline $\mathrm{CH}_{4}$ & \multirow{4}{*}{$\%$ vol } & $50-60$ & $60-75$ & $60-75$ & 68 \\
\hline $\mathrm{CO}_{2}$ & & $34-38$ & $19-33$ & $19-33$ & 26 \\
\hline $\mathrm{N}_{2}$ & & $0-5$ & $0-1$ & $0-1$ & ns \\
\hline $\mathrm{O}_{2}$ & & $0-1$ & $<0,5$ & $<0,5$ & ns \\
\hline $\mathrm{H}_{2} \mathrm{O}$ & $\% \operatorname{vol}\left(\right.$ in $\left.40^{\circ} \mathrm{C}\right)$ & 6 & 6 & 6 & 6 \\
\hline $\mathrm{H}_{2} \mathrm{~S}$ & \multirow{4}{*}{$\mathrm{mg} / \mathrm{m}^{3}$} & $100-900$ & $1000-4000$ & $\begin{array}{l}3000- \\
10,000\end{array}$ & 100 \\
\hline $\mathrm{NH}_{3}$ & & ns & ns & $50-100$ & 400 \\
\hline Aromatic compounds & & $0-200$ & ns & ns & ns \\
\hline $\begin{array}{l}\text { Organic halogenated or } \\
\text { fluoroorganic compounds }\end{array}$ & & $100-800$ & ns & ns & ns \\
\hline
\end{tabular}

ns- not studied

$50-80 \%, 30-50 \%, 2-7 \%, 1-5 \%$, and $0-10 \%$ by volume. Hydrogen sulfide and ammonia contents are suitably in the range of 0-4,000 ppmv and 100-2,000 ppmv (parts per million by volume, at the standard temperature and pressure this means "moles per million, by volume"). The authors [5] also include volatile organic compounds (VOCs) and siloxanes, for which the value is $5-300 \mathrm{mg} / \mathrm{Nm}^{3}$ and $0-50 \mathrm{mg} / \mathrm{Nm}^{3}$, respectively.

Methane is the most valuable component of biogas while the other gaseous substances are considered to be contaminants; they do not improve the energy potential of biogas, and additionally they are corrosive. Biogas produced in agricultural biogas plants generally contains significant amounts of $\mathrm{H}_{2} \mathrm{~S}$ and other volatile sulfur compounds. Biogas, accumulated at landfills packed with of unsorted municipal waste, comprise more halogenated hydrocarbons compared to biogas from other sources, due to waste plastics. Siloxanes used in production of cosmetics and detergents are found in sewage sludge, but since they do not undergo anaerobic digestion they are found both in biogas and the digested sludge [9]. If a renewable fuel is produced from animal waste the final gas mixture is rich in ammonia. The presence of different contaminants in biogas reduces its calorific value. Therefore, the calorific value of the crude biogas is significantly lower than that of natural gas or a compressed natural gas used as a motor fuel compressed natural gas (CNG) [10].

Since biogas is mainly used for electricity or heat production, such applications have to be preceded by removal of $\mathrm{H}_{2} \mathrm{~S}$ and moisture; as corrosive agents, they both have a negative impact on operation and a lifespan of power equipment. To broaden the possible use of biogas, it has to be purified or treated so as to match a natural gas quality. The purification processes remove all gaseous contaminants using special treatment techniques, e.g., adsorption, while during the treatment process biogas is mixed with another gas of superior energy parameters and a higher purity, e.g., propane-butane or natural gas. This new gas mixture is less contaminated than the original biogas [10, 11]. Brudniak et al. [12] identified four ways to increase the calorific value of biogas: enrichment, purification, drying, and deodorization. The first process reduces the amount of $\mathrm{CO}_{2}$, increasing the $\mathrm{CH}_{4} / \mathrm{CO}_{2}$ ratio $[5,12]$. Purification is based mainly on desulfurization, while moisture and odorous substances are removed during drying and deodorization $[3,12]$. The purified biogas can be supplied to gas networks or used as an energy source in gas engines and fuel cells $[10,11,13]$.

\section{Methods of Biogas Desulfurization}

Desulfurization of biogas involves the removal of a $\mathrm{H}_{2} \mathrm{~S}$ from a gas mixture (as a corrosive substance that can damage gas engines) [14]. Contamination of biogas with $\mathrm{H}_{2} \mathrm{~S}$ can be controlled at various stages of biogas production, beginning from raw materials, an anaerobic digestion process, and finally biogas desulfurization [15]. The biogas desulfurization methods include: biological $[16,17]$ and catalytic oxidation, a method with bog iron ore, a wet method, and adsorption techniques. Jędrczak [18] discussed other methods of $\mathrm{H}_{2} \mathrm{~S}$ removal from biogas, based on: dosing of ferrous chloride to a digestion chamber, dosing air to biogas, absorption of chemicals binding $\mathrm{H}_{2} \mathrm{~S}$ in solutions, absorption-oxidation processes, biological methods with bio-filters, and adsorption on activated carbon and alkaline iron oxide beds. Sisani et al. [7] divided the most frequently used desulfurization methods on wet/dry processes and membrane processes.

A dose of iron chloride in a digestion chamber results in bonding of $\mathrm{H}_{2} \mathrm{~S}$ into insoluble iron sulfide, and therefore the produced biogas contains only trace amounts of $\mathrm{H}_{2} \mathrm{~S}$. This method is used for high $\mathrm{H}_{2} \mathrm{~S}$ concentrations and allows us to lower them to a concentration of $100 \mathrm{mg} / \mathrm{m}^{3}$ of biogas. The advantages of this method also include low investment and operating costs, easy monitoring, and application at high $\mathrm{H}_{2} \mathrm{~S}$ concentrations in biogas [18]. 
Another method involves dosing of air to a biogas system. This way biological oxidation of $\mathrm{H}_{2} \mathrm{~S}$ to elemental sulfur takes place [18]. The process engages Thiobacillus bacteria that utilize $\mathrm{CO}_{2}$ (biogas contaminant) as a carbon source. Air is supplied to gas and then they pass through an active biofilm. This method not only purifies biogas, but also enriches it, lowering the $\mathrm{CO}_{2}$ concentration. The $\mathrm{H}_{2} \mathrm{~S}$ content in biogas can be reduced down to a range of $30-150 \mathrm{mg} / \mathrm{m}^{3}$ (reduction by $80-99 \%$ ). When using this method, it should be noted that a biogas mixture with an air content of $6-12 \%$ becomes explosive. Jędrczak [18] stated that a gas mixture was highly corrosive for construction elements; he also emphasized the advantages of this method, such as low investment and operating costs and the possibility of remote process control and monitoring. Nemati et al. [16] conducted a comprehensive literature review on Thiobacillus ferrooxidans used for biogas desulfurization. The bacteria are chemoautotrophic bacteria that are capable of biological oxidation of ferrous irons in a sulfuric acid solution. The iron sulfate (III) solution absorbs $\mathrm{H}_{2} \mathrm{~S}$, which is then oxidized to elemental sulfur. Another product of the reaction is ferric sulfate (II), which is recycled for biological re-oxidation.

Biological methods based on biofiltration in filter beds result in an almost complete (98-99.5\%) removal of sulfur compounds from the gas mixture [19]. The products of microbial oxidation of $\mathrm{H}_{2} \mathrm{~S}$ in filters are elemental sulfur (aprox. 75\%) and sulfates (aprox. 25\%). The concentration of $\mathrm{H}_{2} \mathrm{~S}$ in biogas after desulfurization is below $20 \mathrm{mg}$ $\mathrm{H}_{2} \mathrm{~S} / \mathrm{m}^{3}$ [18].

Wet methods, based on absorption of $\mathrm{H}_{2} \mathrm{~S}$ in the specific solutions, take place in scrubbers and involve elution of $\mathrm{H}_{2} \mathrm{~S}$ from biogas with a working fluid; the solutions include water, $\mathrm{NaOH}$ aqueous solution, and ferric chloride solution, as well as aqueous solutions of alkanolamines. It should be pointed out that the application of the wet methods is limited by the amount of $\mathrm{H}_{2} \mathrm{~S}$ in raw biogas. For example, absorption in a caustic soda solution is cost-effective (economically justified) at biogas production from 50 to $1,200 \mathrm{~m}^{3}{ }_{\mathrm{n}} / \mathrm{h}$ and the $\mathrm{H}_{2} \mathrm{~S}$ content in the product within the range of $0.05-1.5 \%$. One of the big disadvantages of the method is waste; working solutions cannot be regenerated and have to be discharged as waste products. $\mathrm{H}_{2} \mathrm{~S}$ reacts with $\mathrm{NaOH}$ and forms sodium hydrosulfide or sodium sulfide, and because the method is not selective $\mathrm{CO}_{2}$ is bound as sodium bicarbonate. Selective removal of $\mathrm{H}_{2} \mathrm{~S}$ is possible using tertiary amines solutions, e.g., triethanolamines [18].

The high removal of $\mathrm{H}_{2} \mathrm{~S}$ from biogas (over 99\%) is possible with an absorption-oxidation method of desulfurization [18]. The process is carried out in a contact reactor where absorbent, usually an aqueous solution of chelate complex of iron (III), is in contact with a sulfurized biogas. The desulfurization product is a colloidal sulfur (removed from the system) and an iron chelate solution (II), which after oxidation with atmospheric oxygen is recycled to a contact chamber. Jędrczak [18] shows the high efficiency of ethylenediaminetetraacetic acid (EDTA) used in this type of process. Absorption-oxidation methods can be used for biogas loads from 200 to 2,500 $\mathrm{m}_{\mathrm{n}}^{3} / \mathrm{h}$.

The last group of methods used for desulfurization of biogas are adsorption methods, which will be discussed in the next section.

It should be emphasized that when high concentrations of $\mathrm{H}_{2} \mathrm{~S}$ in biogas are observed and high efficiency of desulfurization methods is required removal of $\mathrm{H}_{2} \mathrm{~S}$ in the filter chambers is not sufficient. In such situations, external methods of $\mathrm{H}_{2} \mathrm{~S}$ removal from biogas are recommended, e.g., chemical and physical-chemical precipitation, scrubbing or absorption. However, they are associated with use of some specific chemicals and generation of waste that had to be further processed [17]. Selection of a biogas desulfurization method depends on type of substrate, anaerobic digestion conditions, $\mathrm{H}_{2} \mathrm{~S}$ content, and a site location, which is particularly important when using filter beds, which require more surface area.

\section{Sorbents Used for Biogas Desulfurization}

Adsorbents are porous solids with a highly developed surface area available for adsorption. They are used for separation of liquid/gas mixtures and for removal of air and water pollutants, regardless of their concentrations. Adsorbents have different surface properties, such as surface layer structure and its irregularity, or presence of functional groups and heteroatoms. Also, their porous structure has different features such as size and shape of pores and a function of a pore volume distribution by the average diameter [20].

A main feature of adsorbents is pore size, which determines their possible application. It has been classified by the International Union of Pure and Applied Chemistry, based on differences in adsorption ability. According to the classification, the following groups were identified: micropores, mesopores, and macropores [21]. Their characteristics are shown in Fig. 1.

Fig. 2 presents a breakdown of the most commonly used adsorbents on carbon, mineral-carbon and mineral adsorbents [13, 19].

Activated carbon and its modified structures are the main carbonaceous adsorbents. The materials have an extensive and diverse pore system and show a high selectivity toward adsorbed substances. Activated carbon is obtained from natural raw materials such as wood, peat, coal, lignite, coke, lignin, seeds, fruits, and others [22]. Its chemical composition includes elemental carbon followed by oxygen, sulfur, nitrogen, and hydrogen; their percent content is shown in Table 2.

Activated carbon can be produced in a single stage or a two-stage process. In the first method, there is chemical activation of a mixture composed of a carbon substrate and an activating agent in the form of salt, acid, or hydroxide. In the second one, at first carbonation is carried out and a microcrystalline structure of adsorbent is developed. Then, the physical-chemical activation of the char with an oxidizing gaseous medium, e.g., water vapor, $\mathrm{CO}_{2}$ takes 
place, as well as partial gasification of a carbonaceous material. Carrott et al. [22] produced activated carbon membranes from bark. The carbonization process was carried out in a horizontal tube furnace in a stream of dry nitrogen. The flow rate of the gas was $85 \mathrm{~cm}^{3} / \mathrm{min}$, while the heating temperature was increased by $8^{\circ} \mathrm{C} / \mathrm{min}$ up to 700 and $800^{\circ} \mathrm{C}$. Carbonation was carried out for 30 minutes. The process yield was $24 \%$ in both cases. The activation process was carried out in a nitrogen stream for two hours at $450^{\circ} \mathrm{C}$. An adsorbent of a membrane structure with a micropore width of about $1 \mu \mathrm{m}$ was obtained; the total micropore volume was $0.14 \mathrm{~cm}^{3} / \mathrm{g}$. Choma et al. [23] developed microporous carbon adsorbents from waste Kevlar ${ }^{\circledR}$ fibers; the process consisted of two stages: carbonization and activation with $\mathrm{KOH}$. The final product was powdered activated carbons with a total pore volume of $1.54 \mathrm{~cm}^{3} / \mathrm{g}$ and the maximum specific surface area of $2,660 \mathrm{~m}^{2} / \mathrm{g}$ [23].

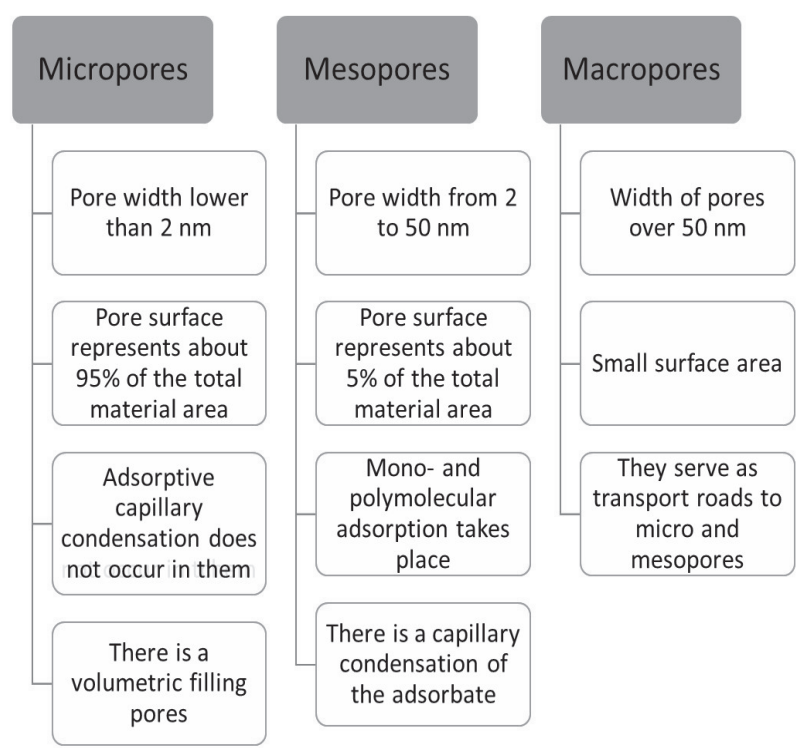

Fig. 1. Pore characteristic according to the IUPAC classification $[20,21]$.

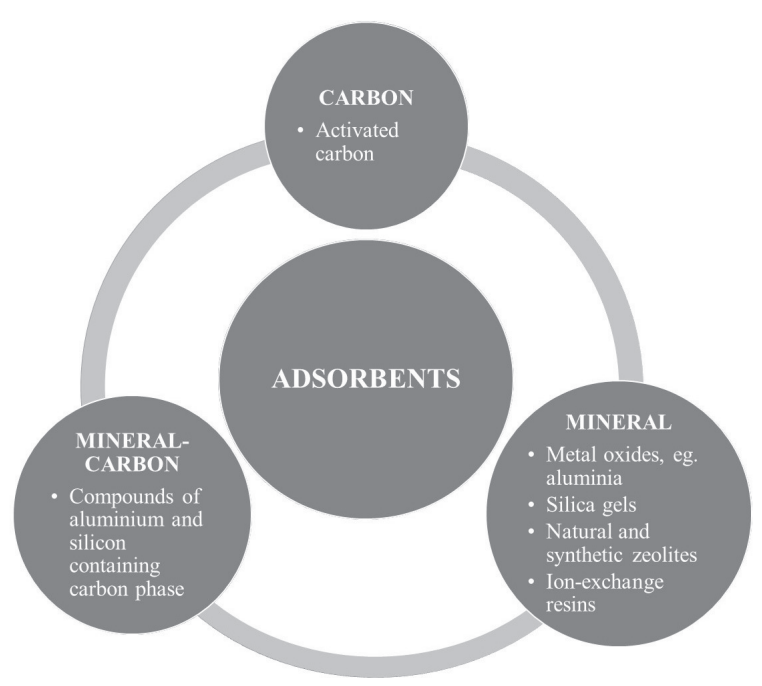

Fig. 2. The most popular adsorbents.
Table 2. Composition of activated carbon (element content percentage).

\begin{tabular}{|c|c|}
\hline Chemical element & Percentage share [\%] \\
\hline C & $85-95$ \\
\hline O & $6-7$ \\
\hline S & 1 \\
\hline N & 0,5 \\
\hline H & 0,5 \\
\hline
\end{tabular}

Activated carbon is one of the most versatile adsorbents with a high removal efficiency and low application costs due to its possible multiple use and possible recovery [13, 24].

The carbonaceous adsorbents are often subjected to modification by carbochemical processing to produce adsorbent for a specific application [7]. Matos et al. [25] used activated carbon modified with titanium oxide in a photocatalytic degradation of phenol in water. Table 3 presents different types of adsorbents, methods for their modification, specific surface areas, and the amount of adsorbed contaminants.

Matos et al. [25] demonstrated that modification of activated carbon structures increases the adsorbent surface area but does not always result in better adsorption of contaminants.

Hernández et al. [6] conducted desulfurization and dehalogenation of a landfill biogas in an ambient temperature, as a part of the European project $\mathrm{BIO} \mathrm{H}_{2}$ Power. The authors used the activated carbon-based adsorbents with the trade names of ROZ3 and RB4W. The adsorbents were modified with $\mathrm{ZnO}$ nanoparticles. This way a material composed of $10 \% \mathrm{ZnO} / \mathrm{ROZ3}$ was obtained, which showed a higher $\mathrm{H}_{2} \mathrm{~S}$ adsorption capacity than ROZ3. It can be explained by the presence of $\mathrm{ZnO}$ nanoparticles, well-dispersed on the surface of activated carbon. The use of two adsorbent beds in series RB4W $+\mathrm{ZnO} / \mathrm{ROZ3}$ enabled efficient desulfurization and dehalogenation of biogas, with a higher removal of halogenated hydrocarbons of a high molecular weight. The solution proposed by Hernández et al. helped to reduce the contaminants below 1 ppmv, while maintaining a high desulfurization efficiency (>99\%) [6].

In the case of the oxide adsorbents the most commonly used are oxides of such metals as $\mathrm{Al}, \mathrm{Fe}, \mathrm{Mn}, \mathrm{Co}, \mathrm{Cu}$, and $\mathrm{Zn}$, depending on their acid-base properties $[7,26]$. They have a well-developed surface of high porosity and good mechanical strength, and are highly temperature resistant. Alumina $\mathrm{Al}_{2} \mathrm{O}_{3}$ has good thermal stability and dielectric properties as well as being resistant to corrosion and oxidation. It comes in different crystallographic forms. Also, silica is used as an adsorbent, usually after impregnation by $\mathrm{CuO}$ and $\mathrm{ZnO}$. Mesoporous silica is used as a carrier of metals and metal oxides due to its structure with available pores of a uniform size and a high surface area; it enables a selective adsorption of contaminants [7, 27]. 
Table 3. Characteristics of a phenol photodegradation in water using a solution of $\mathrm{TiO}_{2}\left(\mathrm{C}_{\mathrm{m}}=10^{-3} \mathrm{~mol} / \mathrm{L}\right)$ with modified carbon adsorbents $\left(\mathrm{mg} \mathrm{TiO}_{2} / \mathrm{mg} \mathrm{AC}^{*}=50 / 10\right)$ [25].

\begin{tabular}{|c|c|c|c|}
\hline Type of carbon adsorbent & Modification & $\mathrm{BET}^{* *}$ surface area $\left(\mathrm{m}^{2} / \mathrm{g}\right)$ & $\begin{array}{l}\text { The amount of adsorbed phenol } \\
\qquad(\mu \mathrm{mol})\end{array}$ \\
\hline No (only $\mathrm{TiO}_{2}$ ) & No & 50 & 1,7 \\
\hline \multirow{3}{*}{ AC-Merck } & No & 780 & 13,4 \\
\hline & $\mathrm{KNO}_{3}$ washing & 1170 & 10,3 \\
\hline & $\mathrm{KOH}$ washing & 830 & 12,8 \\
\hline \multirow{3}{*}{ AC-Purocarbon } & No & 1240 & 6,2 \\
\hline & Vacuum at $250^{\circ} \mathrm{C}$ & 1010 & 4,7 \\
\hline & $\mathrm{KOH}$ washing & 1330 & 5,8 \\
\hline \multirow{3}{*}{ AC-Apamate } & In $\mathrm{H}_{3} \mathrm{PO}_{4}$, in $450^{\circ} \mathrm{C}$ & 1300 & 2,4 \\
\hline & In $\mathrm{CO}_{2}$, in $800^{\circ} \mathrm{C}$ & 640 & 10,1 \\
\hline & In $\mathrm{H}_{2} \mathrm{O}$, in $800^{\circ} \mathrm{C}$ & 420 & 5,9 \\
\hline \multirow{3}{*}{ AC-Algarrobo } & In $\mathrm{H}_{3} \mathrm{PO}_{4}$, in $450^{\circ} \mathrm{C}$ & 1000 & 3,5 \\
\hline & In $\mathrm{CO}_{2}$, in $800^{\circ} \mathrm{C}$ & 520 & 5,7 \\
\hline & In $\mathrm{H}_{2} \mathrm{O}$, in $800^{\circ} \mathrm{C}$ & 450 & 4,2 \\
\hline
\end{tabular}

*AC - Activated carbon

**BET - Brunauer-Emmett-Teller

The following absorbents may serve as examples: $\mathrm{NiO}-\mathrm{CeO}_{2} / \mathrm{Al}_{2} \mathrm{O}_{3}-\mathrm{SiO}_{2}$, which shows high efficiency of $\mathrm{H}_{2} \mathrm{~S}$ adsorption and is used for desulfurization of Jet-A kerosene at ambient conditions [28] as well as the commercial ZnO/SBA-15 and Mn-Cu/SBA-1 [27]. Also, manganese oxide with molybdenum added may be used during desulfurization processes [27]. In the temperature range of $400-1000^{\circ} \mathrm{C}$ it has the highest initial rate of $\mathrm{H}_{2} \mathrm{~S}$ removal, compared with oxides of $\mathrm{Cu}, \mathrm{Zn}, \mathrm{Mn}, \mathrm{Fe}, \mathrm{V}, \mathrm{Mo}, \mathrm{W}, \mathrm{Co}$, $\mathrm{Ca}, \mathrm{Sr}$, and $\mathrm{Ba}$. The reaction end product $\mathrm{MnS}$ becomes completely regenerated at $700^{\circ} \mathrm{C}$ in the presence of water vapor or a concentrated mixture of oxygen and nitrogen. The addition of molybdenum to manganese oxide results in an increased efficiency of adsorption of sulfur compounds [27].

Oxide adsorbents such as $\mathrm{ZnO}$ and $\mathrm{ZnO} / \mathrm{CuO}$ were also used by Kienberger et al. [29], who have carried out the desulfurization process of tar at $350^{\circ} \mathrm{C}$. The authors demonstrated a high desulfurization efficiency using $\mathrm{ZnO} / \mathrm{CuO}$, wherein the concentration of $\mathrm{H}_{2} \mathrm{~S}$ was at the $\mathrm{ppb}$ (parts per billion, $\mu \mathrm{g} / \mathrm{L}$ ) level. Desulfurization with $\mathrm{ZnO}$ resulted in $\mathrm{H}_{2} \mathrm{~S}$ concentrations of approx. $3.5 \mathrm{ppm}$ (parts per million, $\mathrm{mg} / \mathrm{L}$ ) throughout the analysis, while in the case of $\mathrm{ZnO} / \mathrm{CuO}$ such a concentration of $\mathrm{H}_{2} \mathrm{~S}$ was reached after 95 hours [29].

Desulfurization with oxide adsorbents was also carried out by de Arespacochaga et al. [3]. The process of biogas purification had three stages. In the first step, the $\mathrm{H}_{2} \mathrm{~S}$ adsorption on regenerable iron-based adsorbents took place. Then biogas was dried and finally adsorption on activated carbon was carried out to remove residual trace impurities such as siloxanes, and aliphatic and aromatic hydrocarbons. The efficiency of desulfurization was over $99 \%$, and the $\mathrm{H}_{2} \mathrm{~S}$ concentration was below $0.5 \mathrm{ppm}$; the adsorption capacity was $21 \%$ by weight, as determined by the authors. An adsorption mechanism led to oxidation of $\mathrm{H}_{2} \mathrm{~S}$ rather to elemental sulfur and gypsum, then to crystalline iron sulfide, which would explain the poor regeneration of adsorbent (48-60\%). According to the proposed method, application of a three-stage biogas purification system could help to increase the yield of fuel cell projects powered by such biogas [3].

Hussain et al. [30] carried out biogas desulfurization using a mesoporous silica impregnated with zinc oxide in an amount of 10, 15, and $20 \mathrm{wt} \%$. The impregnation was carried out using a dry method, otherwise known as a capillary method (incipient wetness impregnation, or IWI), with the following commercial silica adsorbents: MCM41, KIT-6, SBA-15-spherical (SBA-15-S) and SBA-15 Fibrous (SBA -15-F). All silica adsorbents with $15 \%$ of $\mathrm{ZnO}$ by weight showed a higher adsorption capacity than the adsorbents with 10 and $20 \mathrm{wt} \% \mathrm{ZnO}$. Comparing the results for the materials with 10 and $15 \%$ of $\mathrm{ZnO}$ it may be argued that a better adsorption efficiency is related to a higher content of small zinc oxide particles on a silica surface. A decrease of an adsorption capacity at a higher $\mathrm{ZnO}$ content $(20 \mathrm{wt} \%)$ can be explained by larger particles formed as a result of agglomeration of dispersed forms. The authors also showed that SBA-15 and SBA-F-15-S impregnated with $\mathrm{ZnO}$ showed a higher desulfurization efficiency than the impregnated MCM-41 and KIT-6, as well as the activated carbon-based adsorbent, ROZ3. Hussain et al. in their studies obtained biogas with $\mathrm{H}_{2} \mathrm{~S}$ concentrations below 1 ppmv and a desulfurization efficiency over $99 \%$, at ambient temperature [30]. Also, silica xerogels can be used in biogas desulfurization 
processes after their modification with amino groups, triamines (TRI), or polyethyleneimines (PEI) [31].

Aluminosilicates of alkali metals or alkaline earth metals (i.e., zeolite) are also used as adsorbents. They are not so efficient in $\mathrm{H}_{2} \mathrm{~S}$ adsorption as unmodified and modified carbon adsorbents, therefore modification of the zeolite structure is frequently used to increase its adsorption capacity. They are usually modified by metal ions or metal oxides, in particular copper and zinc. Metals may be incorporated into a zeolite structure by, e.g., the ion exchange process $[7,32]$. A low $\mathrm{H}_{2} \mathrm{~S}$ adsorption on zeolites (less than $0.1 \mathrm{mg} / \mathrm{g}$ ) was confirmed in the studies conducted by Sisani et al. [7]. The authors compared the $\mathrm{H}_{2} \mathrm{~S}$ concentrations adsorbed on several commercial adsorbents such as activated carbons (RGM1, RBAA1 Ultra DS and RB1), ATZ zeolite, alumina Galipur S, and sepiolite. The results are shown in Fig. 3. The best adsorption performance at $30^{\circ} \mathrm{C}$ was observed for activated carbons $\left(\mathrm{C}_{\text {ads }}\right.$ up to $27.15 \mathrm{mg} / \mathrm{g}$ ), while at natural adsorbents - zeolite and sepiolite - the concentrations of the adsorbed $\mathrm{H}_{2} \mathrm{~S}$ were below $0.1 \mathrm{mg} / \mathrm{g}$.

Hernández et al. [13] compared biogas desulfurization efficiencies of six commercial adsorbents: activated carbon impregnated with copper and chromium salts (RGM-3), zeolite 13X, molecular sieves Sylobead 522 and Sylobead 534, and two metal oxides. Fig. 4 shows the biogas desulfurization efficiency as reported by Hernández et al.

The highest desulfurization efficiency was observed on activated carbon, while the lowest was on the

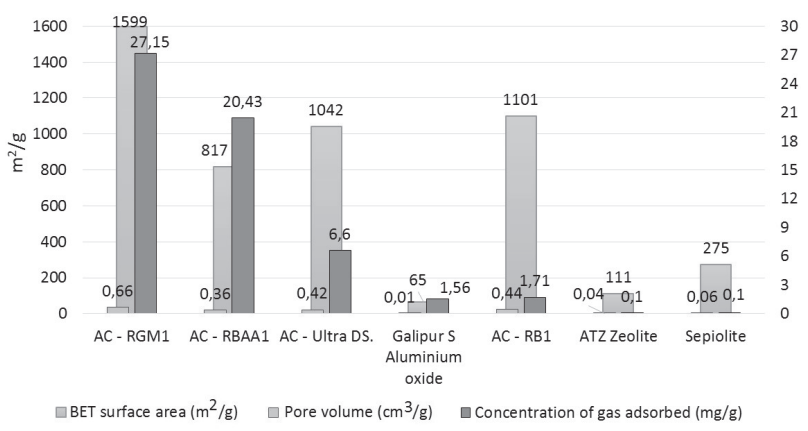

Fig. 3. Characteristics of commercial adsorbents of $\mathrm{H}_{2} \mathrm{~S}$ [7].

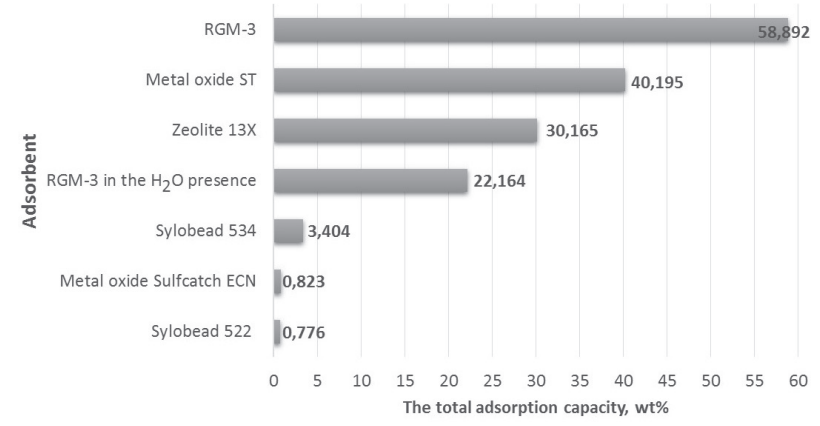

Fig. 4. Biogas desulfurization efficiency of different commercial adsorbents [13]. molecular sieve Sylobead 522. Hernández et al. [33] also demonstrated superiority of carbonaceous adsorbents while studying adsorption of various volatile sulfur compounds in a gas mixture, with methane as the main component. The authors [33] used the same adsorbents as in [13], and showed that the adsorption capacity of sulfur compounds was different as well as the process efficiency; some of the test materials adsorbed contaminants in a selective way. Activated carbons were adsorbents that purified the gas mixture from virtually all sulfur compounds even at room temperature. They showed a high adsorption capacity due to a large surface area and a uniform distribution of pores: micro, meso, and macro [33].

Micoli et al. [32] conducted desulfurization of biogas supplied to fuel cells. The authors used zeolites modified by ion exchange and impregnated with copper and zinc ions, and for comparison activated carbons impregnated with $\mathrm{KOH}, \mathrm{NaOH}$, and $\mathrm{Na}_{2} \mathrm{CO}_{3}$ solutions. It should be emphasized that Micoli et al. took notice of the adsorbent operation time before $\mathrm{H}_{2} \mathrm{~S}$ appeared in the purified gas stream. In the case of zeolites, all modified and impregnated samples showed better results than the original zeolite samples (two times longer adsorbent operation time -300 min.) The most effective was zeolite modified with copper ions during the ion exchange process; its operation time was much longer (more than 600 minutes) than the others at an $\mathrm{H}_{2} \mathrm{~S}$ concentration of $0.5 \mathrm{ppm}$. Much better results were obtained for activated carbon. The best effects were observed for activated carbon impregnated with $\mathrm{Na}_{2} \mathrm{CO}_{3}$, which adsorbed more $\mathrm{H}_{2} \mathrm{~S}$ and was in operation for more than 1,400 minutes, while the other activated carbons could be operated for about 1,000 min. The studies carried out by Micoli et al. [32] confirmed a better performance of carbonaceous adsorbents if compared to zeolites. It should be noted, however, that the adsorption efficiency of sulfur compounds decreases significantly if there is water vapor in a gas mixture [34].

\section{Conclusions}

Desulfurization of biogas is a key process that allows broadening of its use. There are numerous methods of $\mathrm{H}_{2} \mathrm{~S}$ removal, such as, i.e., adsorption techniques that reduce the $\mathrm{H}_{2} \mathrm{~S}$ content below 1 ppmv while maintaining the process efficiency above $99 \%$. Carbon, mineral, and mineral-carbon materials are used as adsorbents. The highest desulfurization efficiency is observed on activated carbons and their modified forms. However, it should be noted that $\mathrm{H}_{2} \mathrm{~S}$ removal on activated carbon decreases significantly when steam is present in a gas mixture. The adsorption capacity for the specific oxide adsorbents ranks above $20 \%$ by weight. However, in the case of zeolites a low desulfurization efficiency is reported, which can be increased by modification of surface silicates. It should be emphasized that biogas desulfurization with adsorbents is effective in the case of low $\mathrm{H}_{2} \mathrm{~S}$ content in the gas mixture. Therefore, for agricultural biogas desulfurization is usually carried out in a different way, e.g. using biological methods. 
Additionally, the application of adsorption techniques for desulfurization results in removal of $\mathrm{CO}_{2}$ and halogenated hydrocarbons from biogas. The method significantly improves its performance and energy potential, strongly confirming the benefits of adsorption methods.

\section{References}

1. HARASIMOWICZ M., ORLUK P., ZAKRZEWSKATRZNADEL G., CHMIELEWSKI A.G. Application of polyimide membranes for biogas purification and enrichment. Journal of Hazardous Materials 144, 698, 2007.

2. GARCÍA G., CASCAROSA E., ÁBREGO J., GONZALO A., SÁNCHEZ J.L. Use of different residues for high temperature desulphurisation of gasification gas. Chemical Engineering Journal 174, 644, 2011.

3. DE ARESPACOCHAGA N., VALDERRAMA C., MESA C., BOUCHY L., CORTINA J.L. Biogas deep clean-up based on adsorption technologies for Solid Oxide Fuel Cell applications. Chemical Engineering Journal 255, 593, 2014.

4. KWAŚNY J., BANACH M., KOWALSKI Z. Przegląd technologii produkcji biogazu różnego pochodzenia, Czasopismo Techniczne seria Chemia 17 (109), 83, 2012.

5. BOCCI E., DI CARLO A., MCPHAIL S.J., GALLUCCI K., FOSCOLO P.U., MONETI M., VILLARINI M., CARLINI M. Biomass to fuel cells state of the art: A review of the most innovative technology solutions. International Journal of Hydrogen Energy 39, 21876, 2014.

6. HERNÁNDEZ S., CHIAPPERO M., RUSSO N., FINO D. A novel $\mathrm{ZnO}$-based adsorbent for biogas purification in $\mathrm{H}_{2}$ production systems. Chemical Engineering Journal 176-177, 272, 2011.

7. SISANI E., CINTI G., DISCEPOLI G., PENCHINI D., DESIDERI U., MARMOTTINI F. Adsorptive removal of $\mathrm{H}_{2} \mathrm{~S}$ in biogas conditions for high temperature fuel cell systems. International Journal of Hydrogen Energy 39, $21753,2014$.

8. Biogas composition, Biogas renewable energy - Information webside on biogas, online access http://www.biogasrenewable-energy.info/

9. GISLON P., GALLI S., MONTELEONE G. Siloxanes removal from biogas by high surface area adsorbents. Waste Management 33 (12), 2687, 2013.

10. BIERNAT K., SAMSON-BRĘK I. Review of technology for cleaning biogas to natural gas quality, Chemik. 65 (5), 435, 2011.

11. HOLEWA J., KUKULSKA-ZAJĄC E. Analysis of the possibility of introducing biogas into the industrial network. 8, 523, 2012 [In Polish].

12. BRUDNIAK A., DĘBOWSKI M., ZIELIŃSKI M. Purification and enrichment of biogas in ash and water slurry, 32, 7, 2013 [In Polish].

13. HERNÁNDEZ S.P., SCARPA F., FINO D., CONTI R. Biogas purification for MCFC application. International Journal of Hydrogen Energy 36 (13), 8112, 2011.

14. GUTIÉRREZ ORTIZ F.J., AGUILERA P.G., OLLERO P. Biogas desulfurization by adsorption on thermally treated sewage-sludge. Separation and Purification Technology 123 200, 2014.

15. PEU P., PICARD S., DIARA A., GIRAULT R., BÉLINE F.,BRIDOUX G., DABERT P. Prediction of hydrogen sulphide production during anaerobic digestion of organic substrates. Bioresource Technology 121, 419, 2012.

16. NEMATI M., HARRISON S.T.L., HANSFORD G.S., WEBB C. Biological oxidation of ferrous sulphate by Thio- bacillus ferrooxidans: a review on the kinetic aspects. Biochemical Engineering Journal 1, 171, 1998.

17. POKORNA D., ZABRANSKA J. Sulfur-oxidizing bacteria in environmental technology, Biotechnology Advances 2015 in press, http://dx.doi.org/10.1016/j.biotechadv.2015.02.007

18. JĘDRCZAK A. Biological treatment of waste, Wyd. PWN, Warszawa 2007, 186, ISBN 978-83-01-15166-9 [In Polish].

19. KWAŚNY J., BALCERZAK W. Characteristics of selected indirect methods of reducing the emission of odors. Archives of Waste Management and Environmental Protection 16, (4), 125, 2014.

20. CHOMA J., JARONIEC M. The porosity of the adsorbent and catalysts: the classical methods of analysis, their capabilities and restrictions. Ochrona Środowiska 2 (81), 3, 2001 [In Polish].

21. BANDOSZ T.J., BIGGS M.J., GUBBINS K.E., HATTORI Y., IIYAMA T., KANEKO K., PIKUNIC J., THOMSON K.T., Molecular models of porous carbons in Chemistry \& Physics of Carbon, L.R. Radovic ed., 42, 2003.

22. CARROTT P.J.M., RIBERIO CARROTT M.M.L., LIMA R.P. Preparation of activated carbon "membranes" by physical and chemical activation of cork, Carbon 37, 515, 1999.

23. CHOMA J., OSUCHOWSKI Ł., DZIURA A., KWIATKOWSKA-WÓJCIK W., JARONIEC M. Adsorption properties of activated carbons obtained from fibers Kelvar, Ochrona Środowiska 36 (4), 3, 2014 [In Polish].

24. CHOMA J., OSUCHOWSKI Ł., JARONIEC M. Properties and the use of activated carbons derived from mineral polymer. Ochrona Środowiska 36 (2), 3, 2014 [In Polish].

25. MATOS J., LAINE J., HERRMANN J-M. Association of activated carbons of different origins with titania in the photocatalytic purification of water, Carbon 37, 1870, 1999.

26. GIL-LALAGUNA N., SÁNCHEZ J.L., MURILLO M.B., GEA G. Use of sewage sludge combustion ash and gasification ash for high-temperature desulphurization of different gas streams, Fuel 141, 99, 2015.

27. ZHANG Z.F., LIU B.S., WANG F., ZHENG S. High-temperature desulfurization of hot coal gas on Mo modified $\mathrm{Mn} /$ KIT-1 sorbents, Chemical Engineering Journal (2015), doi: http://dx.doi.org/10.1016/j.cej.2015.02.091

28. XU X., ZHANG S., LI P., SHEN Y. Adsorptive desulfurization of liquid Jet-A fuel at ambient conditions with an improved adsorbent for on-board fuel treatment for SOFC applications, Fuel Processing Technology 124, 140, 2014.

29. KIENBERGER T., ZUBER C., NOCOSEL K., BAUMHAKL C., KARL J. Desulfurization and in situ tar reduction within catalytic methanation of biogenous synthesis gas, Fuel 107, 102, 2013.

30. HUSSAIN M., ABBAS N., FINO D., RUSSO N. Novel mesoporous silica supported $\mathrm{ZnO}$ adsorbents for the desulphurization of biogas at low temperatures, Chemical Engineering Journal 188, 222, 2012.

31. JAIBOON V., YOOSUK B., PRASASSARAKICH P. Amine modified silica xerogel for $\mathrm{H}_{2} \mathrm{~S}$ removal at low temperature, Fuel Processing Technology 128, 276-282, 2014.

32. MICOLI L., BAGNASCO G., TURCO M. $\mathrm{H}_{2} \mathrm{~S}$ removal from biogas for fuelling MCFCs: New adsorbing materials, International Journal of Hydrogen Energy 39, 1783, 2014.

33. HERNÁNDEZ S., SOLARINO L., ORSELLO G., RUSSO N., FINO D., SARACCO G., SPECCHIA V. Desulfurization processes for fuel cells systems. International Journal of Hydrogen Energy 33, 3209, 2008.

34. BARELLI L., BIDINI G., GALLORINI F. $\mathrm{H}_{2} \mathrm{~S}$ absorption on activated carbons NoritRB1: CFD model development, Fuel Processing Technology 100, 35, 2012. 
